\title{
Review
}

Neonatology

\section{Novel Echocardiography Methods in the Functional Assessment of the Newborn Heart}

\author{
Colm R. Breatnach ${ }^{a}$ Philip T. Levy ${ }^{d, e} \quad$ Adam T. James $^{a}$ Orla Franklin ${ }^{b}$ \\ Afif El-Khuffash ${ }^{a, c}$

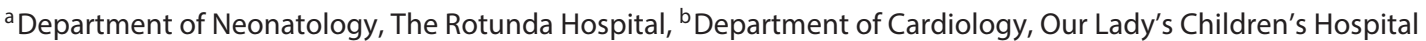 \\ Crumlin, and 'Department of Paediatrics, School of Medicine, Royal College of Surgeons in Ireland, Dublin, Ireland; \\ dDepartment of Paediatrics, Washington University School of Medicine, St. Louis, Mo., and 'Goryeb Children's \\ Hospital, Atlantic Health System, Morristown, N.J., USA
}

\section{Key Words}

Neonatology · Echocardiography · Cardiac function .

Deformation · Tissue Doppler · Strain

\begin{abstract}
Echocardiography in the neonatal intensive care unit has led to improvements in our ability to assess the neonatal heart in health and disease. Advances in neonatal cardiac imaging have provided the capability to obtain quantitative information that often supersedes the qualitative information provided by conventional methods. Novel quantitative measures of function include the assessment of the velocity of muscle tissue movement during systole and diastole using tissue Doppler velocity imaging, and evaluation of deformation and rotational characteristics of the myocardium utilizing speckle tracking echocardiography or tissue Doppler-derived strain imaging. A comprehensive understanding of these novel functional modalities, their predictive value, and limitations can greatly assist in managing both the normal and maladaptive responses in the newborn period. This article discusses the novel and emerging methods for assessment of left and right heart function in the neonatal population.

(c) 2016 S. Karger AG, Basel
\end{abstract}

The role of functional echocardiography in the neonatal intensive care unit for the evaluation of infant cardiovascular well-being has significantly expanded over the last 10 years [1-3]. The use of echocardiography in the neonatal intensive care unit, also referred to as targeted neonatal echocardiography, has been shown to identify cardiovascular compromise earlier, guide therapeutic intervention, monitor treatment response, and improve overall outcome [4-6].

Advances in neonatal cardiac imaging have provided the capability to obtain quantitative information that often supersedes the qualitative information provided by conventional methods. Conventional function measures, such as shortening (SF) and ejection fraction (EF), assess the changes in cavity dimensions. Newer quantitative measures assess the velocity of muscle tissue movement during systole and diastole in one image using colour tissue Doppler velocity imaging (cTDI), and evaluate deformation and rotational characteristics of the myocardium utilizing speckle tracking echocardiography (STE) or tissue Doppler-derived strain imaging. In addition, there is

Colm R. Breatnach and Philip T. Levy equally contributed to writing the first draft of the review.

\section{KARGER}

E-Mail karger@karger.com

www.karger.com/neo (c) 2016 S. Karger AG, Basel

$1661-7800 / 16 / 1104-0248 \$ 39.50 / 0$
Prof. A. El-Khuffash, Consultant Neonatologist Department of Neonatology, The Rotunda Hospital Parnell Street

IE-Dublin 1 (Ireland)

E-Mail afifelkhuffash@ rcsi.ie 
Table 1. Recommendations for the echocardiographic assessment of LV and RV function in neonates

\begin{tabular}{|c|c|c|c|c|c|}
\hline $\begin{array}{l}\text { Echocardio- } \\
\text { graphic imaging }\end{array}$ & Recommended methods & $\begin{array}{l}\text { Populations studies } \\
\text { in neonates }\end{array}$ & $\begin{array}{l}\text { Reference } \\
\text { ranges }\end{array}$ & Advantages & Limitations \\
\hline Tissue Doppler & $\begin{array}{l}\text { Longitudinal myocardial } \\
\text { motion velocity is measured } \\
\text { at the mitral valve annulus, } \\
\text { tricuspid valve annulus, and } \\
\text { the base of the septum }\end{array}$ & $\begin{array}{l}\text { Preterm [25, 26, 29, 30, } \\
44,57,58] \\
\text { Healthy [22] } \\
\text { PDA [31] } \\
\text { BPD [74] } \\
\text { PRBC tx [32, 33] } \\
\text { Term } \\
\text { Healthy [22-24, 28, 30] } \\
\text { Encephalopathy [36] } \\
\text { Sepsis [38] } \\
\text { CDH [35] }\end{array}$ & $\begin{array}{l}\text { Dependent on } \\
\text { GA and postnatal } \\
\text { age }\end{array}$ & $\begin{array}{l}\text { Improved accuracy } \\
\text { compared to SF and EF } \\
\text { Less effected by } \\
\text { paradoxical septal wall } \\
\text { motion } \\
\text { Simultaneous assessment } \\
\text { of muscle wall velocity } \\
\text { across different } \\
\text { myocardial segments }\end{array}$ & $\begin{array}{l}\text { Influenced by loading } \\
\text { conditions }\end{array}$ \\
\hline \multicolumn{6}{|l|}{ Deformation } \\
\hline cDTI & $\begin{array}{l}\text { The region of interest is } \\
\text { placed at the basal area of } \\
\text { the wall of interest }\end{array}$ & $\begin{array}{l}\text { Preterm }[44,50,60,61] \\
\text { CLD [50] } \\
\text { Term } \\
\text { Healthy }[46,75] \\
\text { CHD [48] }\end{array}$ & $\begin{array}{l}\text { Dependent on } \\
\text { GA and postnatal } \\
\text { age }\end{array}$ & $\begin{array}{l}\text { Very suitable in neonates } \\
\text { with baseline fast HR } \\
\text { Less dependent on loading } \\
\text { conditions }\end{array}$ & Angle dependent \\
\hline$\overline{\text { STE }}$ & $\begin{array}{l}\text { LV global longitudinal strain } \\
\text { is calculated from a 17- or } \\
\text { 18-segment model by } \\
\text { segmental averaging of the } \\
\text { three apical views, apical 4-, } \\
\text { 3-, and 2-chamber views } \\
\text { Circumferential and radial } \\
\text { strains are obtained from the } \\
\text { parasternal short-axis view } \\
\text { at the level of the papillary } \\
\text { muscle (base) mitral valve } \\
\text { (mid-ventricular), and apex } \\
\text { Rotational mechanics is } \\
\text { derived from the parasternal } \\
\text { short-axis view at the base } \\
\text { and apex }\end{array}$ & $\begin{array}{l}\text { Preterm }[41,49,57,58] \\
\text { Healthy [62] } \\
\text { CLD [62] } \\
\text { Term [59] } \\
\text { Healthy [52] } \\
\text { Hypothermia [14] }\end{array}$ & $\begin{array}{l}\text { Dependent on } \\
\text { GA and postnatal } \\
\text { age } \\
\text { Different for RV } \\
\text { and LV strain } \\
\text { imaging }\end{array}$ & $\begin{array}{l}\text { Assess global and regional } \\
\text { function of both ventricles } \\
\text { Established prognostic } \\
\text { value }\end{array}$ & $\begin{array}{l}\text { Lower reproducibility } \\
\text { with diastolic strain } \\
\text { rate values }\end{array}$ \\
\hline \multicolumn{6}{|l|}{$R V$ function } \\
\hline TAPSE & $\begin{array}{l}\text { Derived from M-mode, } \\
\text { cTDI, or STE analysis of the } \\
\text { lateral tricuspid annular ring }\end{array}$ & $\begin{array}{l}\text { Preterm }[68] \\
\text { Term }[28,68,70]\end{array}$ & $\begin{array}{l}\text { Dependent on } \\
\text { GA and postnatal } \\
\text { age } \\
>0.9 \mathrm{~mm}\end{array}$ & $\begin{array}{l}\text { Correlates with RV } \\
\text { ejection fraction on MRI } \\
\text { Unaffected by heart rate }\end{array}$ & $\begin{array}{l}\text { Not indexed to RV } \\
\text { length } \\
\text { Angle dependent } \\
\text { Influenced by loading } \\
\text { and tricuspid } \\
\text { regurgitation } \\
\text { No imaging of the } \\
\text { outflow tract }\end{array}$ \\
\hline$\overline{\mathrm{FAC}}$ & $\begin{array}{l}\text { Calculated by tracing the RV } \\
\text { endocardium from the } \\
\text { lateral tricuspid annulus } \\
\text { along the free wall to the } \\
\text { apex and back to medial } \\
\text { tricuspid annulus, along } \\
\text { the interventricular septum in } \\
\text { end-diastole (RV EDA) and } \\
\text { end-systole (RV ESA) } \\
\text { Trabeculations are considered } \\
\text { part of the cavity by tracing } \\
\text { RV EDA and RV ESA } \\
\text { between RV trabeculations } \\
\text { and the compact layer of the } \\
\text { ventricle } \\
\text { FAC = } 100\left[\text { RV EDA }\left(\mathrm{cm}^{2}\right)-\right. \\
\left.\text { RV ESA }\left(\mathrm{cm}^{2}\right)\right] / \text { RV EDA } \mathrm{cm}^{2} \text { ) }\end{array}$ & $\begin{array}{l}\text { Preterm }[44,65] \\
\text { Term } \\
\text { Healthy }[28]\end{array}$ & $\begin{array}{l}\text { Dependent on } \\
\text { GA and postnatal } \\
\text { age }[73] \\
35 \%[28]\end{array}$ & $\begin{array}{l}\text { Utilizes standard } \\
\text { echocardiographic } \\
\text { equipment } \\
\text { Less affected by RV } \\
\text { geometry }\end{array}$ & $\begin{array}{l}\text { Influenced by loading } \\
\text { conditions } \\
\text { Less reproducible }\end{array}$ \\
\hline
\end{tabular}


Table 1 (continued)

\begin{tabular}{|c|c|c|c|c|c|}
\hline $\begin{array}{l}\text { Echocardio- } \\
\text { graphic imaging }\end{array}$ & Recommended methods & $\begin{array}{l}\text { Populations studies } \\
\text { in neonates }\end{array}$ & $\begin{array}{l}\text { Reference } \\
\text { ranges }\end{array}$ & Advantages & Limitations \\
\hline \multicolumn{6}{|l|}{ Novel methods } \\
\hline 3D STE & $\begin{array}{l}\text { Strain is derived from the } \\
\text { 3D full-volume data sets } \\
\text { with the apical four- } \\
\text { chamber, two-chamber, } \\
\text { long-axis view, and short- } \\
\text { axis views } \\
\text { 3D strain is calculated as the } \\
\text { vector sum of the } \\
\text { longitudinal and } \\
\text { circumferential strain } \\
\text { components, ignoring the } \\
\text { radial component }\end{array}$ & & $\begin{array}{l}\text { Normal data does } \\
\text { not exist for } \\
\text { neonates }\end{array}$ & $\begin{array}{l}\text { Correlates with cardiac } \\
\text { MRI }\end{array}$ & $\begin{array}{l}\text { Not validated for } \\
\text { radial shortening }\end{array}$ \\
\hline 3D EF & $\begin{array}{l}\text { Volumetric semi-automated } \\
\text { border detection approach is } \\
\text { the recommended method } \\
\text { for the assessment of RV EF }\end{array}$ & & $\begin{array}{l}\text { Normal data does } \\
\text { not exist for } \\
\text { neonates }\end{array}$ & $\begin{array}{l}\text { Ability to assess RV } \\
\text { ejection fraction } \\
\text { Measure of overall RV } \\
\text { performance }\end{array}$ & $\begin{array}{l}\text { Load dependent } \\
\text { Interventricular } \\
\text { changes affecting } \\
\text { septal motion } \\
\text { Poor acoustic windows }\end{array}$ \\
\hline
\end{tabular}

an emerging set of validated measures to assess right ventricular (RV) function in neonates that includes percent fractional area change (FAC) and tricuspid annular plane systolic excursion (TAPSE). This expanding body of literature details methodology (feasibility and reproducibility), reference ranges, and diagnostic/predictive ability of all these parameters with respect to neonatal cardiopulmonary health and disease (table 1).

\section{Conventional Methods of Assessment of Function}

Monitoring the cardiovascular status of sick and/or premature newborn infants remains a challenge due to the insensitivity of conventional echocardiographic measures to assess cardiac output and myocardial performance $[7,8]$. Assessment of left ventricular (LV) output and RV output as a surrogate for systemic blood flow is challenged by the presence of shunts in early neonatal life. Superior vena cava flow is also suggested as a surrogate of blood flow from the upper body circulation. However, there are challenges with the reproducibility of this measurement and no information is provided by superior vena cava flow on blood flow to the lower body $[9,10]$.

SF can assess LV function using M-mode from either a long parasternal axis or short-axis view of the left ventricle, and is dependent on the change in cavity dimensions in one plane. SF is inaccurate in the presence of septal wall paradoxical motion, which often occurs with high $\mathrm{RV}$ pressures during the transitional period or with per- sistent pulmonary hypertension [11]. EF may provide a better assessment of LV function in the presence of paradoxical septal motion, but both SF and EF are heavily influenced by ventricular preload as they assess cardiac function by measuring changes in cavity dimension rather than by directly analyzing muscle wall properties. The Simpson's biplane method for EF measurement is recommended as an alternative to $\mathrm{M}$-mode in the presence of regional wall motion abnormalities [2]. It involves manual tracing of the LV cavity endocardium from the 4-chamber view and a modified 2-chamber view at endsystole and end-diastole (fig. 1).

The prognostic value of EF and SF has been shown to be inferior to novel quantitative measures for predicting major adverse cardiac events in adults [12]. In neonates, SF and EF lack the sensitivity to detect subtle or preclinical changes in myocardial function when compared with newer methods such as TDI and STE $[8,13,14]$. SF and $\mathrm{EF}$ are also not suitable for the assessment of RV function due to the complex geometry of the right ventricle [15]. The limitations of these conventional echocardiography methods have hindered the assessment of myocardial performance in many critical neonatal conditions.

\section{Tissue Doppler Velocity Imaging}

Tissue Doppler velocity imaging (TDI) is a quantitative echocardiographic modality that measures the velocity of muscle movement directly from the myocardi- 
Fig. 1. Simpson's biplane method for EF measurement. The apical 4-chamber (4C) view is used as a starting point. Most modern echocardiography machines have an option to measure EF using Simpson's biplane method. The LV cavity in the $4 \mathrm{C}$ view is traced at the end of diastole (maximal area) and then at the end of systole (minimal area). The probe is then angled anticlockwise until the RV chamber is no longer visible to obtain the 2 -chamber $(2 \mathrm{C})$ view. The LV cavity is traced again in systole and diastole. The machine's software should then calculate the EF.
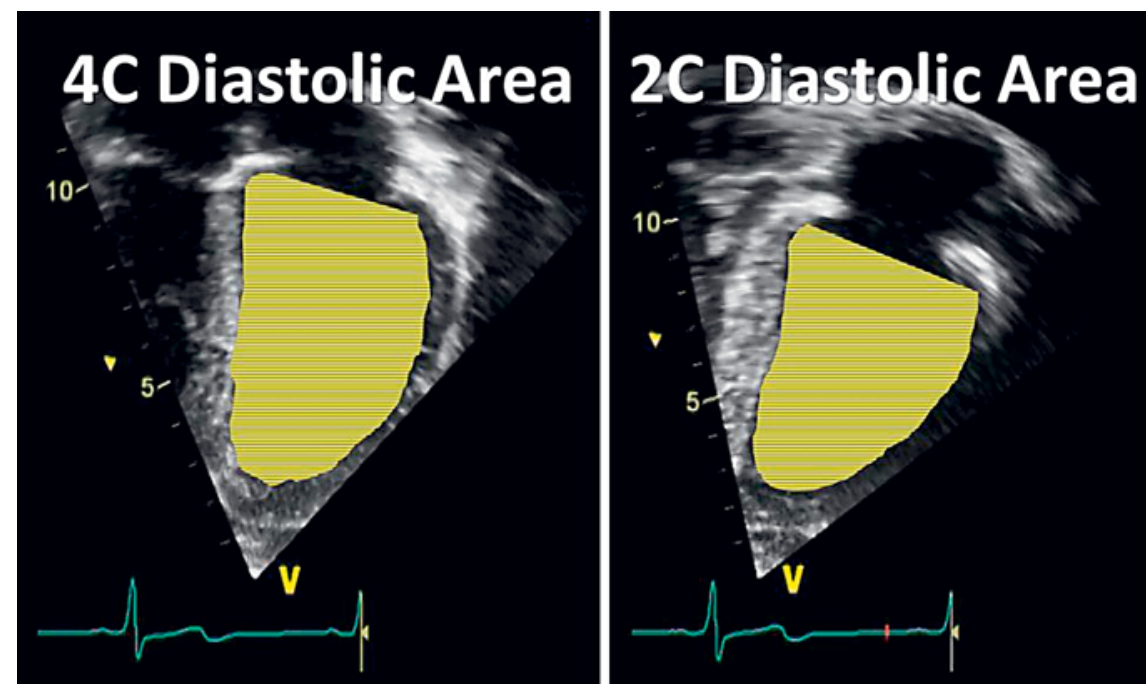

\section{C Systolic Area}
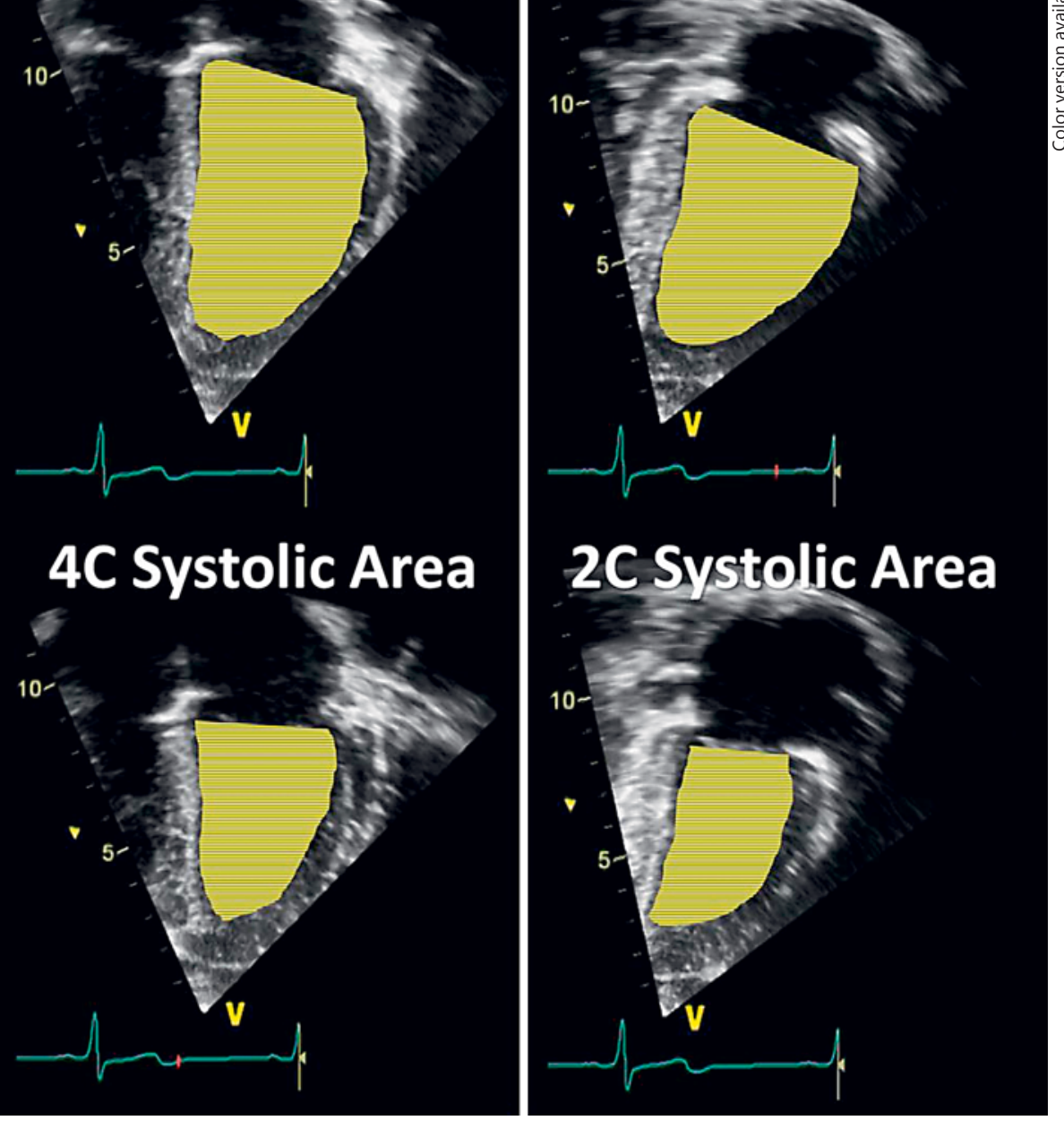

um by filtering out high-velocity signals obtained from the movement of blood to focus on the lower velocity Doppler signals of the muscle walls. Longitudinal myocardial motion velocity (from base to apex in systole and the reverse in diastole) can be measured at the mitral and tricuspid valve annuli and the base of the septum. With TDI, systolic function is obtained by measuring the peak systolic velocity of the myocardial muscle (s' wave) [16, 17] and diastolic function is measured at two time points [18]: (1) the peak early diastolic velocity (e'), and (2) the peak late (or atrial phase) velocity (a'). TDI can be performed in pulsed-wave (pw) and colour (c) modes (fig. 2a, b). pwTDI is used to measure peak myocardial velocities and has high temporal resolution, but does not permit simultaneous analysis of multiple myocardial segments. Compared with pwTDI, cTDI increases spa- tial resolution and provides visualization of multiple segments of the heart from one single view. The velocities obtained from cTDI are 20\% lower than those obtained from pwTDI, so the two methods are not interchangeable $[17,19]$.

TDI has been validated in adult $[17,20]$, paediatric $[16$, $21]$, and neonatal populations $[22,23]$, as well as in foetuses [24], and has demonstrated acceptable reliability. Normative reference values now exist for preterm and term infants [25-28]. Lower gestational age preterm infants have lower myocardial velocities in both systole and diastole $[26,29,30]$. Reduced myocardial velocity is also present during the transitional period from the foetal to the neonatal circulation, and increases over the first few weeks. TDI provides a more accurate assessment of myocardial dysfunction than SF and EF [8,31-33]. TDI can 
Fig. 2. a Tissue Doppler velocity measurement using pulsed waves. Diagram 1 shows the apical 4-chamber view with colour tissue Doppler. A colour-coded representation of myocardial velocities is superimposed on gray-scale $2 \mathrm{D}$ or $\mathrm{M}$-mode images to indicate the direction and velocity of myocardial motion. The three small yellow boxes (colour in online version only) indicate the place where the pulsed-wave Doppler cursor is placed to measure velocity (from left to right: tricuspid annulus, septum, mitral valve annulus). Diagram 2 shows the corresponding pulsed-wave Doppler signal with the $y$-axis showing the velocity in $\mathrm{cm} / \mathrm{s}$ : $\mathrm{s}$ ' is the peak systolic ve-

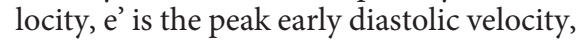
and a' is the peak late diastolic velocity. Diagram 3 shows the pulsed-wave Doppler signal from a premature infant. Notice the e'/a' wave reversal indicative of abnormal diastolic function. b Colour tissue Doppler velocity assessment. This mode facilitates simultaneous assessment of muscle wall velocity across different myocardial segments. This method can only be derived offline. The 4-chamber view image (in colour Doppler and gray scale) illustrates the region of interest of where the velocities were obtained. RV systolic velocity (red line) starts before septal (yellow line) and LV (green line) velocities (colour in online version only).
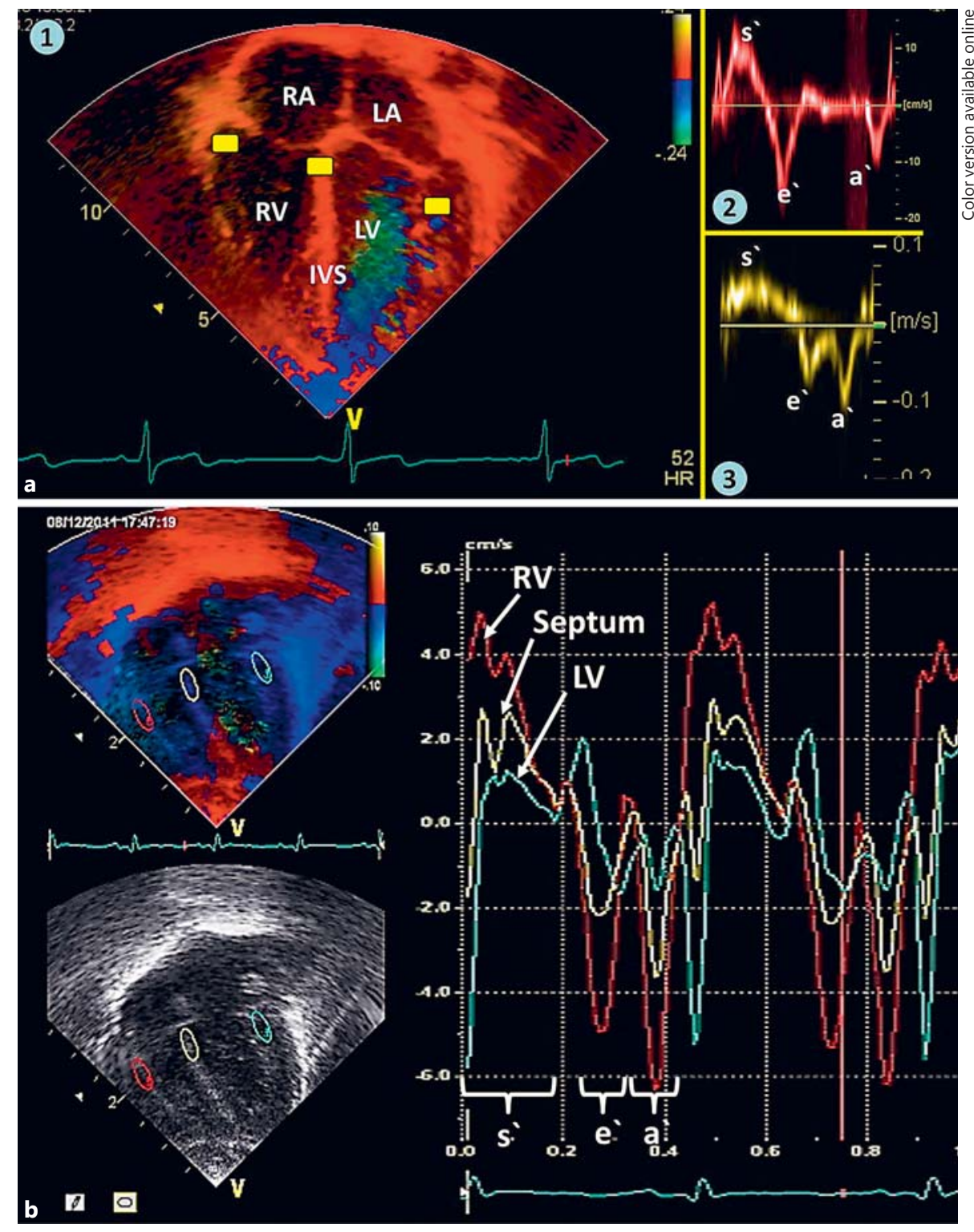

assess both global and regional myocardial performance and is less affected by paradoxical septal wall motion [34]. TDI is more sensitive in detecting and monitoring myocardial dysfunction in critically ill preterm infants and term infants with congenital diaphragmatic hernia and neonatal sepsis [35-38]. TDI may also provide functional haemodynamic data to assist in outcome prediction models [35-39]. TDI is positively influenced by increasing preload, and negatively influenced by increasing afterload $[24,31]$.

\section{Deformation Imaging}

Deformation refers to a change in the shape of the myocardium in multiple planes from its baseline shape at end-diastole to its deformed shape at end-systole. LV and $\mathrm{RV}$ deformation patterns are different and are based on their own unique architectural patterns. The LV myocardium consists of longitudinal fibres in the endocardial and epicardial layers, and circumferential fibres in the mid-wall layer [40]. LV deformation during systole comprises longitudinal shortening, circumferential shortening, and radial thickening. Compared with the left ven- 
Fig. 3. Tissue Doppler-derived measurement of strain and SR. The region of interest used for this technique is placed at the basal area of the wall of interest. During aortic valve opening (AVO), the wall segment strain is at baseline. Peak systolic strain is identified at the time of aortic valve closure (AVC). Peak systolic SR occurs in mid-systole (SRS). The early (SRE) and late (SRA) diastolic SR occur between mitral valve opening (MVO) and mitral valve closure (MVC).
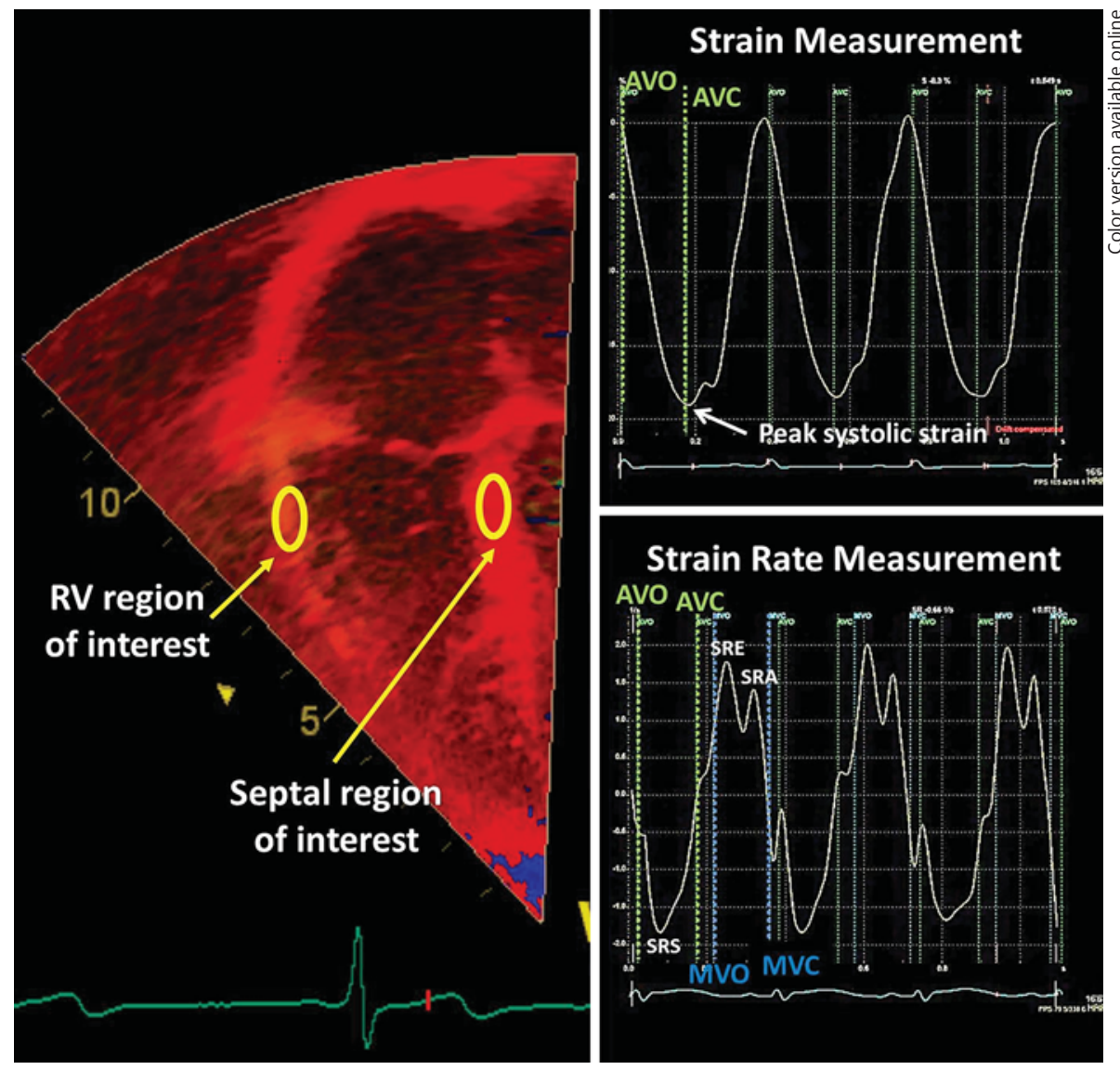

tricle, the shape of the thin-walled RV cavity is more complex and the RV myofibre architecture is composed of superficial oblique and dominant deep longitudinal layers. Longitudinal shortening is the dominant deformation of the RV that provides the major contribution to stroke volume during systole [41].

Myocardial strain $(\varepsilon)$ and strain rate (SR), which describe the longitudinal, circumferential, and radial deformation in the left ventricle and the longitudinal deformation in the right ventricle under an applied force, have been demonstrated to be feasible and sensitive quantitative measures of LV function in neonates [31, 42-46]. Strain is a measure of absolute tissue deformation during systole and is expressed as a percentage change from baseline. It is assigned a negative sign for shortening (in longitudinal and circumferential planes) and a positive sign for thickening in the radial plane. Strain is influenced by preload (which increases wall strain) and afterload (which reduces wall strain) [8]. SR measures the time course of deformation (velocity of shortening/time unit), and provides one value in systole representing the rate at which the deformation occurs, and two values in diastole representing the early and late phase rates of return to baseline. It is thought to be less dependent on loading conditions [47], and may be a closer reflection of contractility. Strain and SR may be used to assess global and regional function in both ventricles [48]. There are two different echocardiographic methods used to measure tissue deformation: (1) cDTI and colour Doppler myocardial imaging and (2) two-dimensional (2D) STE

cDTI measures the velocity gradient of two points over a segment with a fixed distance in the myocardium. Strain is described as a displacement gradient (spatial derivative of displacement) and SR as the velocity gradient (spatial derivative of velocity) (fig. 3). Strain is calculated as a spatial derivative of SR, is measured along the beam of the ultrasound, and is insonation angle dependent. CDTI is better suited for measurement of SR values in neonates (with a higher baseline heart rate) as it employs a natural SR calculation method with much higher frame rates (high temporal resolution) $[49,50]$. This technique is highly feasible and reproducible, but 

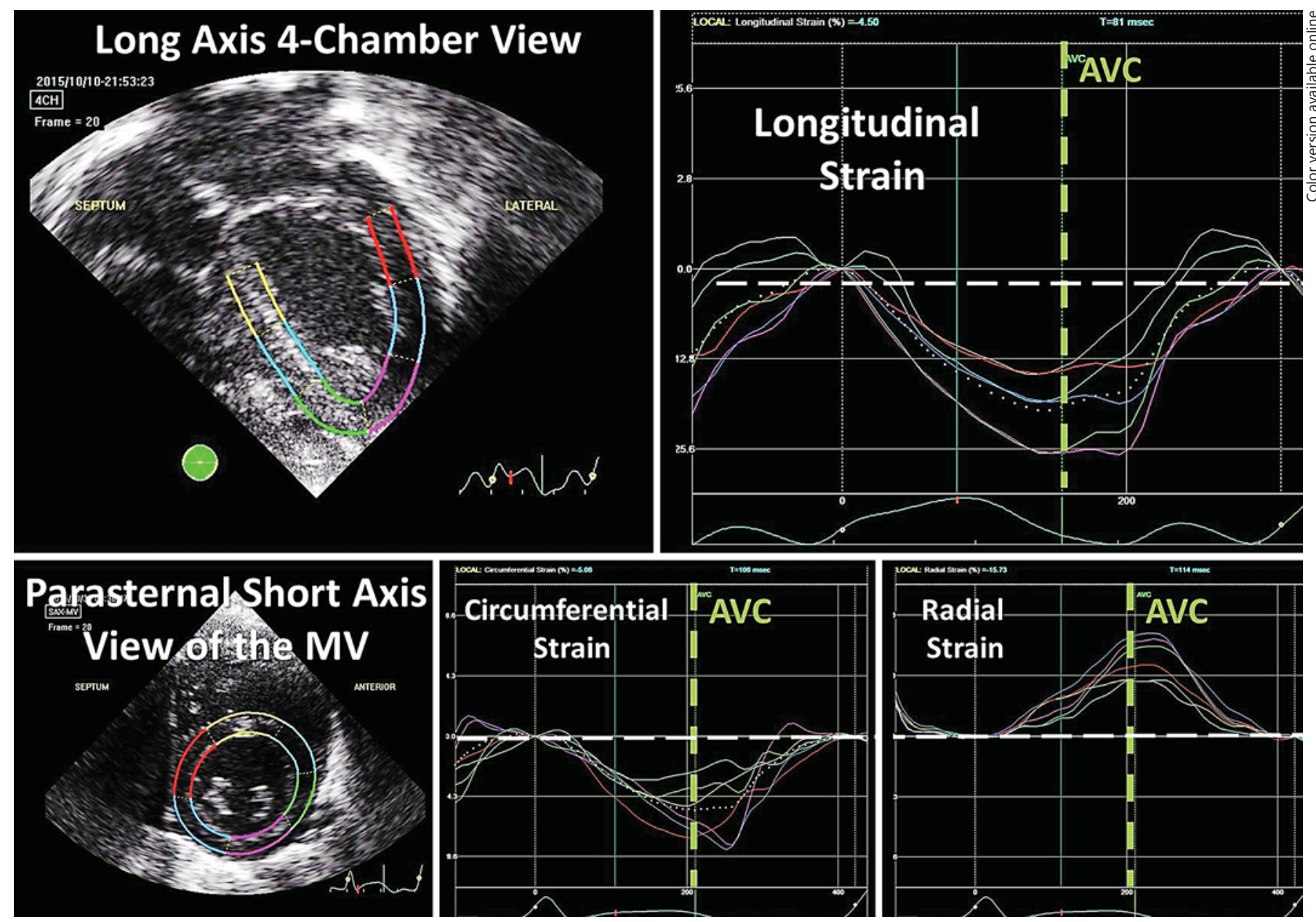

Fig. 4. Speckle tracking method for calculation of strain. The top panel shows the assessment of the left ventricle by the offline analysis software in six segments (4-chamber view). The speckle tracking algorithm divides the LV myocardium into 6 segments (basal septum, mid-septum, apical septum, basal lateral, mid-lateral, and apical lateral) and generates 7 curves, 6 specific myocardial segments, and 1 global value representing the combined strain from all segments; the LV global longitudinal strain from a 17- or 18-segment model is calculated from segmental averaging of the three apical views: apical 4-, 3-, and 2-chambers. The bottom panel demonstrates circumferential and radial strains obtained from the parasternal short-axis view at the level of the mitral valve. $\mathrm{AVC}=$ Aortic valve closure.

2D-STE imaging uses standard B-mode images for speckle tracking analysis [12]. The speckle patterns are the result of acoustic backscatter generated by the reflected ultrasound beam. Speckles represent fixed tissue markers, or 'natural acoustic markers', that are randomly distributed throughout the myocardium and have their own unique signature or 'fingerprint' [52]. The movement of this speckled pattern follows myocardial tissue motion as it tracks the defined region of speckles, frame by frame and eventually over the entire heart cycle, and extracts the displacement (the movement of those speckles), velocity (the speed at which this movement occurs), strain (the 
Fig. 5. Left ventricle rotational mechanics. The base of the left ventricle rotates in a clockwise fashion (depicted as a negative rotation) and the apex of the left ventricle rotates in an anticlockwise fashion (depicted as a positive rotation). The net difference between those opposing rotational movements is LV twist. The rate of twist $(\%)$ in systole and early untwist in diastole are illustrated as well.
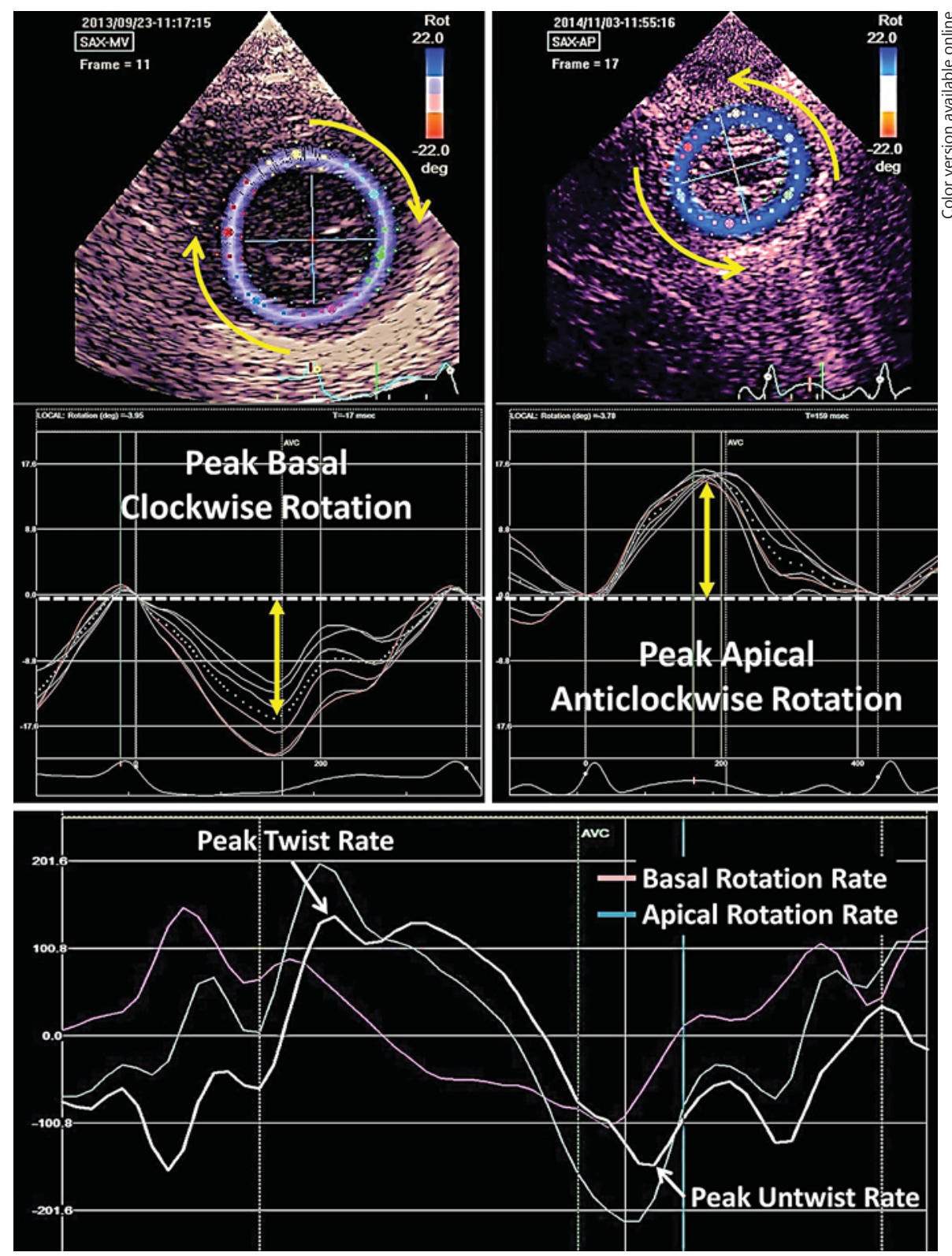

relative change in distance between those speckles), and SR (the speed at which the change in distance occurs) of a defined myocardial segment (fig. 4). STE is angle independent and gives true longitudinal strain, as the movement of speckles can be followed in any direction [53]. In the three apical image views, STE allows for calculation of longitudinal and transverse parameters. In short-axis images, both circumferential and radial parameters can be calculated for all myocardial segments $[42,54,55]$. STEderived LV and RV strain demonstrates high clinical feasibility and reproducibility in term and preterm infants with appropriate frame rate:heart rate ratios $[8,31,41,44$, 56]. However, STE (as compared to TDI) employs relatively lower frame rates to derive SR measurements and the assessment of SR parameters in preterm infants using STE currently has lower reproducibility [41].

There is an expanding body of literature on strain and SR in term and preterm infants using both cDTI and STE techniques $[8,31,44,49,56-58]$. Current research is evaluating the ability of $\varepsilon$ and SR to characterize the physiological and pathological changes in diseases such hypoxic ischaemic encephalopathy, pulmonary hypertension, li- 

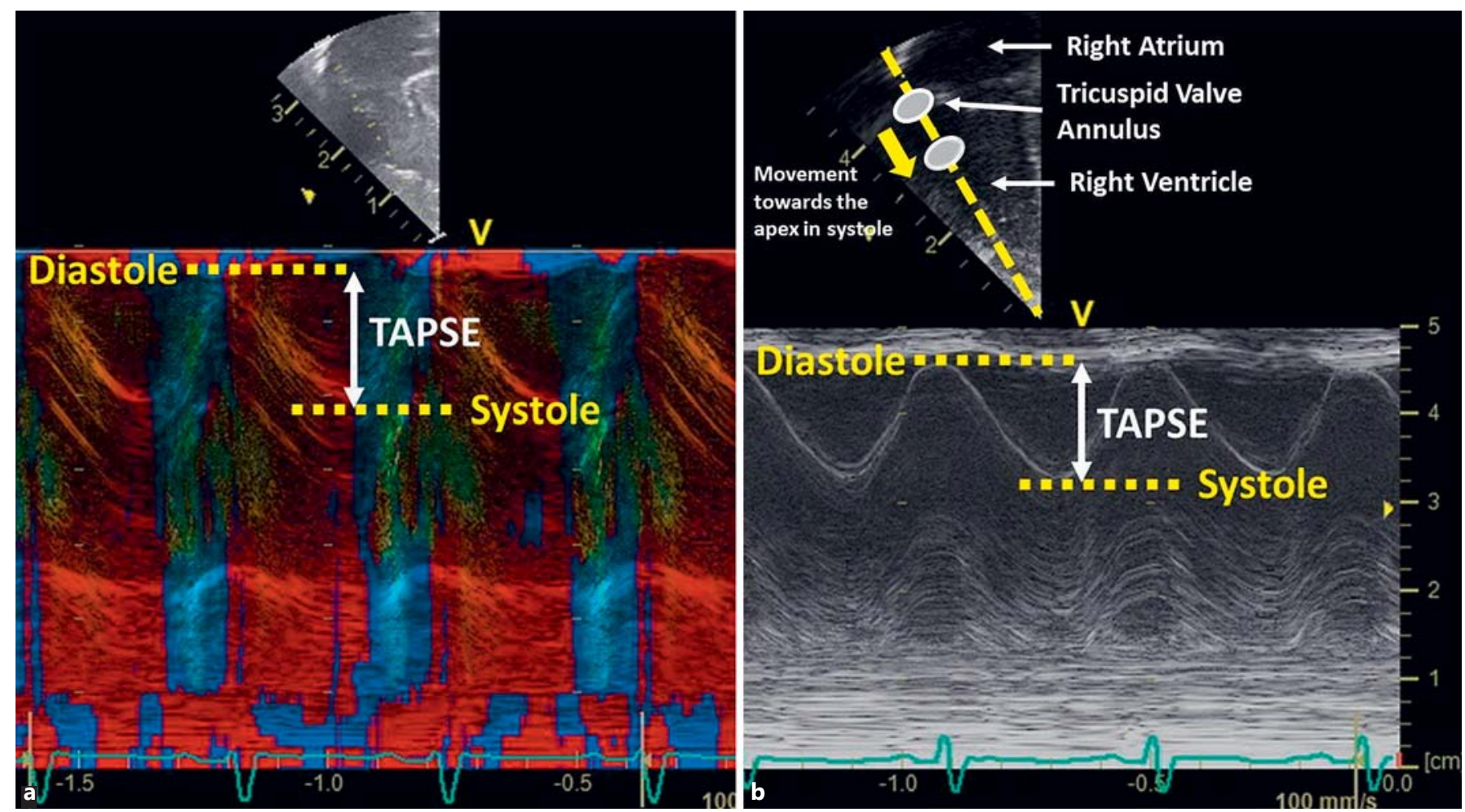

Fig. 6. TAPSE measurement. Assessment of the movement of the annular plane towards the apex can be carried out in Tissue Doppler (a) and 2D M-mode (b). TAPSE is acquired with the cursor optimally aligned along the direction of the tricuspid lateral annulus in the RV-focused apical 4-chamber view and measured between enddiastole and peak systole.

gation of a patent ductus arteriosus, and chronic lung disease. [14, 28, 31, 41, 43, 59-61]. Furthermore, longitudinal reference ranges of LV and RV strain and SR (including the septum) in term and preterm infants are emerging and are a necessary prerequisite to evaluating cardiopulmonary health and disease in neonates [62].

\section{Rotational Mechanics}

LV twist describes the wringing motion of the LV during systole, and is the net result of the contrasting rotation of the apex (in an anticlockwise direction, depicted as a positive rotation) and the base (in a clockwise direction, depicted as a negative rotation) along the long axis of the left ventricle; both are expressed in degrees. LV torsion is the term given to LV twist indexed to its length. This wringing motion, which is also expressed in degrees, improves the ejection of blood from the LV cavity during systole. LV untwist contributes directly to early diastolic filling and is influenced by muscle fibre compliance and elastic recoil properties. The speed at which LV twist occurs (LV twist rate) and LV untwist occurs (LV untwist rate) can also be measured and expressed as degrees per second (fig. 5). These rotational parameters add important information on myocardial performance [63]. The twisting motion of the LV is aided by the helical arrangement of the subepicardial (left handed) and subendocardial (right handed) fibres [7]. Untwist is facilitated by the kinetic energy stored in those twisted fibres which is released during diastole due to elastic recoil. Therefore, the LV untwist rate in early diastole is highly influenced by LV twist in systole. Reduced LV twist will therefore translate to a reduced LV untwist rate [27]. Increased afterload appears to decrease the LV twist and untwist rates in experimental animal models and human adults [64]. Similarly, in the preterm neonatal population, increased afterload appears to negatively impact those measurements [65]. 
Fig. 7. Calculation FAC. RV FAC is calculated by tracing the RV endocardium in EDA and end-systole ESA. Trabeculations are considered part of the cavity by tracing RV EDA and RV ESA between RV trabeculations and the compact layer of the ventricle. $\mathrm{FAC}=100\left[\mathrm{RV}\right.$ EDA $\left(\mathrm{cm}^{2}\right)-\mathrm{RV}$ $\left.\operatorname{ESA}\left(\mathrm{cm}^{2}\right)\right] / R V$ EDA $\left(\mathrm{cm}^{2}\right)$.
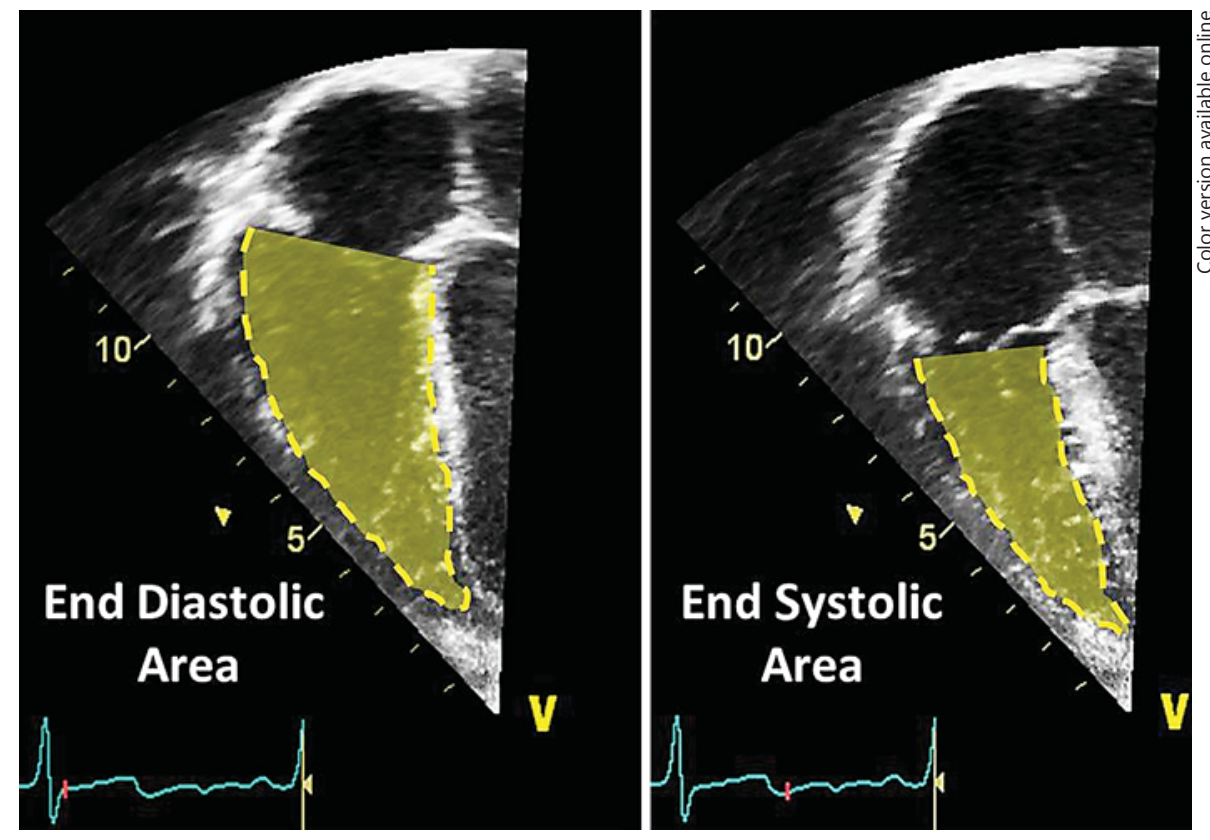

Rotational mechanics can be assessed by STE in a similar fashion to the method described above and demonstrates acceptable agreement with twist measured by magnetic resonance imaging (MRI) $[63,66]$. Twist as a marker of cardiac function has been validated in adults and children $[45,67]$. Rotational mechanics data in term neonates during the early transitional period is lacking. There are limited studies of those parameters in preterm infants $[27,65]$. Our group has recently demonstrated the feasibility and acceptable reproducibility of measuring LV twist in the premature population, in addition to the changes occurring over the first week of age [27]. We have also demonstrated that increased systemic vascular resistance over the first day of age has a negative impact on LV twist and untwist [65].

\section{RV-Specific Markers of Cardiac Performance}

Accurate assessment of RV performance can be challenging [15], but RV function is a critical prognostic determinant of cardiopulmonary pathologies in term and preterm infants. RV-specific markers of function have recently emerged. These include TAPSE and FAC $[19,46$, 68].

TAPSE measures movement of the tricuspid annulus from base to apex during systole and reflects global RV systolic function (fig. 6). This is an absolute measurement of the distance travelled by the annulus during systole and is not indexed to the length of the right ventricle. It has been validated as an accurate measure of RV function in adult and pediatric patients $[69,70]$ with further research on term and preterm infants demonstrating its acceptable reliability $[28,44,68]$. The impact of lower gestation and postnatal age reveals a reduction in annular displacement which is consistent with other modalities [30]. TAPSE has been proven to show better reproducibility than other methods of RV assessment [71] and has shown a correlation with RV EF determined by MRI. It is not influenced by heart rate, which is of importance for its use in preterm infants [72]. In order to compare TAPSE across different gestations and heart size, some advocate indexing the measurement to RV length.

RV FAC is a quantitative measurement of RV function. RV FAC expresses the percentage change in the RV chamber area between end-diastole (EDA) and end-systole (ESA). Calculation of FAC can be easily performed using standard echocardiographic equipment and does not require any geometric assumptions (fig. 7). Although FAC is affected by loading conditions, it is less sensitive to abnormal geometry and regional abnormalities. RV FAC measurements in term and preterm infants are highly reproducible $[28,44,73]$. Reference values for RV RV EDA, RV ESA, and FAC have been identified in the neonatal population for both term and preterm infants [73]. As expected, there is an increase in $\mathrm{RV}$ areas and FAC 
with gestational age and a linear increase with weight [28]. In the transitional period, RV areas and RV FAC remain relatively stable in healthy term infants. However, in preterm infants the RV ESA and RV FAC increase in the transitional period, while RV EDA remains stable. This increase in FAC is most likely because of a smaller RV ESA (compared with healthy term infants), 'which likely reflects the decreased afterload imposed on the RV by a slowly decreasing pulmonary vascular resistance' [44].

\section{Conclusion}

The methods to diagnose and manage cardiac function with echocardiography in term and preterm infants must be firmly understood and established before routine clinical adoption can be implemented and incorporated into neonatal guidelines. The novel echocardiography methods to assess cardiac function that are now available have been validated in stable preterm infants and healthy term infants. Despite the push to standardize the acquisition of these measures and reduce intervendor differences and ambiguities, it is important for the reader to review any details of hardware settings, manual settings, and local imaging protocols to get a better understanding of the values presented. The next phase is to determine the applicability of these novel measures of myocardial performance as a means for assessing the efficacy of patient management strategies in health and disease. We need to understand their ability to direct management, monitor treatment response and predict outcomes to optimize the care we deliver to term and preterm infants. In addition, exploring further novel methods of functional assessment, including 3D-STE and 3D-echocardiography-derived $\mathrm{RV}$ volume and $\mathrm{EF}$ is warranted.

\section{Acknowledgement}

This work was funded by a Friends of the Rotunda Research Grant which covered the publication costs of this manuscript.

\section{Disclosure Statement}

The authors report no conflicts of interest.

\section{References}

1 Evans N, Gournay V, Cabanas F, Kluckow M, Leone T, Groves A, McNamara P, Mertens L: Point-of-care ultrasound in the neonatal intensive care unit: international perspectives. Semin Fetal Neonatal Med 2011;16:61-68.

2 Mertens L, Seri I, Marek J, Arlettaz R, Barker P, McNamara P, Moon-Grady AJ, Coon PD, Noori S, Simpson J, Lai WW; Writing Group of the American Society of Echocardiography; European Association of Echocardiography; Association for European Pediatric Cardiologists: Targeted neonatal echocardiography in the neonatal intensive care unit: practice guidelines and recommendations for training Writing Group of the American Society of Echocardiography (ASE) in collaboration with the European Association of Echocardiography (EAE) and the Association for European Pediatric Cardiologists (AEPC). J Am Soc Echocardiogr 2011;24:1057-1078.

3 Singh Y, Gupta S, Groves AM, Gandhi A, Thomson J, Qureshi S, Simpson JM: Expert consensus statement 'neonatologist-performed echocardiography (NoPE)'-training and accreditation in UK. Eur J Pediatr 2016; $175: 281-287$
4 Carmo KB, Evans N, Paradisis M: Duration of indomethacin treatment of the preterm patent ductus arteriosus as directed by echocardiography. J Pediatr 2009;155:819-822.

5 El-Khuffash A, Herbozo C, Jain A, Lapointe A, McNamara PJ: Targeted neonatal echocardiography (TnECHO) service in a Canadian neonatal intensive care unit: a 4-year experience. J Perinatol 2013;33:687-690.

6 Jain A, Sahni M, El-Khuffash A, Khadawardi E, Sehgal A, McNamara PJ: Use of targeted neonatal echocardiography to prevent postoperative cardiorespiratory instability after patent ductus arteriosus ligation. J Pediatr 2012;160:584-589.

7 Alagarsamy S, Chhabra M, Gudavalli M, Nadroo AM, Sutija VG, Yugrakh D: Comparison of clinical criteria with echocardiographic findings in diagnosing PDA in preterm infants. J Perinat Med 2005;33:161-164.

8 El-Khuffash AF, Jain A, Weisz D, Mertens L, McNamara PJ: Assessment and treatment of post patent ductus arteriosus ligation syndrome. J Pediatr 2014;165:46-52.

9 El-Khuffash AF, McNamara PJ: Neonatologist-performed functional echocardiography in the neonatal intensive care unit. Semin $\mathrm{Fe}$ tal Neonatal Med 2011;16:50-60.
10 Lee A, Liestøl K, Nestaas E, Brunvand L, Lindemann R, Fugelseth D: Superior vena cava flow: feasibility and reliability of the off-line analyses. Arch Dis Child Fetal Neonatal Ed 2010;95:F121-F125.

11 Lee LA, Kimball TR, Daniels SR, Khoury P, Meyer RA: Left ventricular mechanics in the preterm infant and their effect on the measurement of cardiac performance. J Pediatr 1992;120:114-119.

12 Kalam K, Otahal P, Marwick TH: Prognostic implications of global LV dysfunction: a systematic review and meta-analysis of global longitudinal strain and ejection fraction. Heart 2014;100:1673-1680.

13 Sehgal A, Wong F, Menahem S: Speckle tracking derived strain in infants with severe perinatal asphyxia: a comparative case control study. Cardiovasc Ultrasound 2013;11: 34.

14 Czernik C, Rhode S, Helfer S, Schmalisch G, Buhrer C: Left ventricular longitudinal strain and strain rate measured by $2-\mathrm{D}$ speckle tracking echocardiography in neonates during whole-body hypothermia. Ultrasound Med Biol 2013;39:1343-1349. 
15 Mertens LL, Friedberg MK: Imaging the right ventricle - current state of the art. Nat Rev Cardiol 2010;7:551-563.

16 Hiarada K, Orino T, Yasuoka K, Tamura M, Takada G: Tissue Doppler imaging of left and right ventricles in normal children. Tohoku J Exp Med 2000;191:21-29.

17 Nagueh SF, Middleton KJ, Kopelen HA, Zoghbi WA, Quinones MA: Doppler tissue imaging: a noninvasive technique for evaluation of left ventricular relaxation and estimation of filling pressures. J Am Coll Cardiol 1997;30:1527-1533.

18 Yu CM, Sanderson JE, Marwick TH, Oh JK: Tissue Doppler imaging: a new prognosticator for cardiovascular diseases. J Am Coll Cardiol 2007;49:1903-1914.

19 Frommelt PC, Ballweg JA, Whitstone BN, Frommelt MA: Usefulness of Doppler tissue imaging analysis of tricuspid annular motion for determination of right ventricular function in normal infants and children. Am J Cardiol 2002;89:610-613.

20 Sohn DW, Chai IH, Lee DJ, Kim HC, Kim HS, Oh BH, Lee MM, Park YB, Choi YS, Seo JD, Lee YW: Assessment of mitral annulus velocity by Doppler tissue imaging in the evaluation of left ventricular diastolic function. J Am Coll Cardiol 1997;30:474-480.

21 Eidem BW, McMahon CJ, Cohen RR, Wu J, Finkelshteyn I, Kovalchin JP, Ayres NA, Bezold LI, O'Brian Smith E, Pignatelli RH: Impact of cardiac growth on Doppler tissue imaging velocities: a study in healthy children. J Am Soc Echocardiogr 2004;17:212221.

22 Negrine RJ, Chikermane A, Wright JG, Ewer AK: Assessment of myocardial function in neonates using tissue Doppler imaging. Arch Dis Child Fetal Neonatal Ed 2012;97:F304F306.

23 Alp H, Karaarslan S, Baysal T, Cimen D, Ors $\mathrm{R}$, Oran B: Normal values of left and right ventricular function measured by M-mode, pulsed Doppler and Doppler tissue imaging in healthy term neonates during a 1-year period. Early Hum Dev 2012;88:853-859.

24 Iwashima S, Sekii K, Ishikawa T, Itou H: Serial change in myocardial tissue Doppler imaging from fetus to neonate. Early Hum Dev 2013;89:687-692.

25 Murase M, Morisawa T, Ishida A: Serial assessment of right ventricular function using tissue Doppler imaging in preterm infants within 7 days of life. Early Hum Dev 2015;91: 125-130.

26 Murase M, Morisawa T, Ishida A: Serial assessment of left-ventricular function using tissue Doppler imaging in premature infants within 7 days of life. Pediatr Cardiol 2013;34: 1491-1498.

27 James A, Corcoran JD, Mertens L, Franklin O, El-Khuffash A: Left ventricular rotational mechanics in preterm infants less than 29 weeks' gestation over the first week after birth. J Am Soc Echocardiogr 2015;28:808817.
28 Jain A, Mohamed A, El-Khuffash A, Connelly KA, Dallaire F, Jankov RP, McNamara PJ, Mertens L: A comprehensive echocardiographic protocol for assessing neonatal right ventricular dimensions and function in the transitional period: normative data and $\mathrm{z}$ scores. J Am Soc Echocardiogr 2014;27:1293-1304.

29 Lee A, Nestaas E, Liestøl K, Brunvand L, Lindemann R, Fugelseth D: Tissue Doppler imaging in very preterm infants during the first $24 \mathrm{~h}$ of life: an observational study. Arch Dis Child Fetal Neonatal Ed 2014;99:F64-F69.

30 Eriksen BH, Nestaas E, Hole T, Liestøl K, Stoylen A, Fugelseth D: Myocardial function in term and preterm infants. Influence of heart size, gestational age and postnatal maturation. Early Hum Dev 2014;90:359-364.

31 El-Khuffash AF, Jain A, Dragulescu A, McNamara PJ, Mertens L: Acute changes in myocardial systolic function in preterm infants undergoing patent ductus arteriosus ligation: a tissue Doppler and myocardial deformation study. J Am Soc Echocardiogr 2012;25:10581067.

32 Saleemi MS, Bruton K, El-Khuffash A, Kirkham C, Franklin O, Corcoran JD: Myocardial assessment using tissue Doppler imaging in preterm very low-birth weight infants before and after red blood cell transfusion. J Perinatol 2013;33:681-686.

33 Saleemi MS, El-Khuffash A, Franklin O, Corcoran JD: Serial changes in myocardial function in preterm infants over a four week period: the effect of gestational age at birth. Early Hum Dev 2014;90:349-352.

34 Pellerin D, Sharma R, Elliott P, Veyrat C: Tissue Doppler, strain, and strain rate echocardiography for the assessment of left and right systolic ventricular function. Heart 2003; 89(suppl 3):iii9-iiil7.

35 Moenkemeyer F, Patel N: Right ventricular diastolic function measured by tissue Doppler imaging predicts early outcome in congenital diaphragmatic hernia. Pediatr Crit Care Med 2014; 15:49-55

36 Matter M, Abdel-Hady H, Attia G, Hafez M, Seliem W, Al-Arman M: Myocardial performance in asphyxiated full-term infants assessed by Doppler tissue imaging. Pediatr Cardiol 2010;31:634-642.

37 Murase M, Ishida A, Momota T: Serial pulsed Doppler assessment of early left ventricular output in critically ill very low-birth-weight infants. Pediatr Cardiol 2002;23:442-448.

38 Abdel-Hady HE, Matter MK, El-Arman MM: Myocardial dysfunction in neonatal sepsis: a tissue Doppler imaging study. Pediatr Crit Care Med 2012;13:318-323

39 El-Khuffash A, James AT, Corcoran JD, Dicker P, Franklin O, Elsayed YN, Ting JY, Sehgal A, Malikiwi A, Harabor A, Soraisham AS, McNamara PJ: A patent ductus arteriosus severity score predicts chronic lung disease or death before discharge. J Pediatr 2015;167: 1354-1361.e2.

40 Greenbaum RA, Ho SY, Gibson DG, Becker $\mathrm{AE}$, Anderson RH: Left ventricular fibre ar- chitecture in man. Br Heart J 1981;45:248263.

41 Levy PT, Holland MR, Sekarski TJ, Hamvas A, Singh GK: Feasibility and reproducibility of systolic right ventricular strain measurement by speckle-tracking echocardiography in premature infants. J Am Soc Echocardiogr 2013;26:1201-1213.

42 Abraham TP, Dimaano VL, Liang HY: Role of tissue Doppler and strain echocardiography in current clinical practice. Circulation 2007; 116:2597-2609.

43 Nestaas E, Stoylen A, Sandvik L, Brunvand L, Fugelseth D: Feasibility and reliability of strain and strain rate measurement in neonates by optimizing the analysis parameters settings. Ultrasound Med Biol 2007;33:270278 .

44 James AT, Corcoran JD, Jain A, McNamara PJ, Mertens L, Franklin O, El-Khuffash AF: Assessment of myocardial performance in preterm infants less than 29 weeks gestation during the transitional period. Early Hum Dev 2014;90:829-835.

45 Zhang Y, Zhou QC, Pu DR, Zou L, Tan Y: Differences in left ventricular twist related to age: speckle tracking echocardiographic data for healthy volunteers from neonate to age 70 years. Echocardiography 2010;27:1205-1210.

46 Pena JL, da Silva MG, Faria SC, Salemi VM, Mady C, Baltabaeva A, Sutherland GR: Quantification of regional left and right ventricular deformation indices in healthy neonates by using strain rate and strain imaging. J Am Soc Echocardiogr 2009;22:369-375.

47 Sutherland GR, Di SG, Claus P, D'hooge J, Bijnens B: Strain and strain rate imaging: a new clinical approach to quantifying regional myocardial function. J Am Soc Echocardiogr 2004;17:788-802.

48 Weidemann F, Eyskens B, Mertens L, Dommke C, Kowalski M, Simmons L, Claus P, Bijnens B, Gewillig M, Hatle L, Sutherland GR: Quantification of regional right and left ventricular function by ultrasonic strain rate and strain indexes after surgical repair of tetralogy of Fallot. Am J Cardiol 2002;90:133-138.

49 de Waal K, Lakkundi A, Othman F: Speckle tracking echocardiography in very preterm infants: Feasibility and reference values. Early Hum Dev 2014;90:275-279.

50 James AT, Corcoran JD, Breatnach CR, Franklin O, Mertens L, El-Khuffash A: Longitudinal assessment of left and right myocardial function in preterm infants using strain and strain rate imaging. Neonatology 2016; 109:69-75.

51 Voigt JU, Pedrizzetti G, Lysyansky P, Marwick $\mathrm{TH}$, Houle $\mathrm{H}$, Baumann $\mathrm{R}$, Pedri S, Ito Y, Abe Y, Metz S, Song JH, Hamilton J, Sengupta PP, Kolias TJ, d'Hooge J, Aurigemma GP, Thomas JD, Badano LP: Definitions for a common standard for $2 \mathrm{D}$ speckle tracking echocardiography: consensus document of the EACVI/ASE/Industry Task Force to standardize deformation imaging. J Am Soc Echocardiogr 2015;28:183-193. 
52 Lorch SM, Ludomirsky A, Singh GK: Maturational and growth-related changes in left ventricular longitudinal strain and strain rate measured by two-dimensional speckle tracking echocardiography in healthy pediatric population. J Am Soc Echocardiogr 2008;21: 1207-1215.

53 Koopman LP, Slorach C, Hui W, Manlhiot C, McCrindle BW, Friedberg MK, Jaeggi ET, Mertens L: Comparison between different speckle tracking and color tissue Doppler techniques to measure global and regional myocardial deformation in children. J Am Soc Echocardiogr 2010;23:919-928.

54 Pavlopoulos H, Nihoyannopoulos P: Strain and strain rate deformation parameters: From tissue Doppler to 2D speckle tracking. Int J Cardiovasc Imaging 2008;24:479-491.

55 Bijnens BH, Cikes M, Claus P, Sutherland GR Velocity and deformation imaging for the assessment of myocardial dysfunction. Eur J Echocardiogr 2009; 10:216-226.

56 Sanchez AA, Levy PT, Sekarski TJ, Hamvas A, Holland MR, Singh GK: Effects of frame rate on two-dimensional speckle tracking-derived measurements of myocardial deformation in premature infants. Echocardiography 2015; 32:839-847.

57 Hirose A, Khoo NS, Aziz K, Al-Rajaa N, van den Boom J, Savard W, Brooks P, Hornberger LK: Evolution of left ventricular function in the preterm infant. J Am Soc Echocardiogr 2015;28:302-308.

58 de Waal K, Phad N, Lakkundi A, Tan P: Cardiac function after the immediate transitional period in very preterm infants using speckle tracking analysis. Pediatr Cardiol 2016;37: 295-303.

59 Cantinotti M, Kutty S, Giordano R, Assanta N, Murzi B, Crocetti M, Marotta M, Iervasi G: Review and status report of pediatric left ventricular systolic strain and strain rate nomograms. Heart Fail Rev 2015;20:601-612.

60 Helfer S, Schmitz L, Buhrer C, Czernik C: Reproducibility and optimization of analysis parameters of tissue Doppler-derived strain and strain rate measurements for very low birth weight infants. Echocardiography 2013;30: $1219-1226$
61 Helfer S, Schmitz L, Buhrer C, Czernik C: Tissue Doppler-derived strain and strain rate during the first 28 days of life in very low birth weight infants. Echocardiography 2013;31: 765-772.

62 Czernik C, Rhode S, Helfer S, Schmalisch G, Buhrer C, Schmitz L: Development of left ventricular longitudinal speckle tracking echocardiography in very low birth weight infants with and without bronchopulmonary dysplasia during the neonatal period. PLoS One 2014;9:e106504.

63 Buckberg G, Hoffman JI, Nanda NC, Coghlan C, Saleh S, Athanasuleas C: Ventricular torsion and untwisting: further insights into mechanics and timing interdependence: a viewpoint. Echocardiography 2011;28:782-804.

64 Burns AT, La GA, Prior DL, Macisaac AI: Left ventricular torsion parameters are affected by acute changes in load. Echocardiography 2010;27:407-414.

65 James AT, Corcoran JD, Hayes B, Franklin O, El-Khuffash A: The effect of antenatal magnesium sulfate on left ventricular afterload and myocardial function measured using deformation and rotational mechanics imaging. J Perinatol 2015;35:913-918.

66 Huang SJ, Orde S: From speckle tracking echocardiography to torsion: research tool today, clinical practice tomorrow. Curr Opin Crit Care 2013;19:250-257.

67 Kaku K, Takeuchi M, Tsang W, Takigiku K, Yasukochi S, Patel AR, Mor-Avi V, Lang RM, Otsuji Y: Age-related normal range of left ventricular strain and torsion using three-dimensional speckle-tracking echocardiography. J Am Soc Echocardiogr 2014;27:55-64.

68 Koestenberger M, Nagel B, Ravekes W, Urlesberger B, Raith W, Avian A, Halb V, Cvirn G, Fritsch P, Gamillscheg A: Systolic right ventricular function in preterm and term neonates: reference values of the tricuspid annular plane systolic excursion (TAPSE) in 258 patients and calculation of $\mathrm{z}$-score values. Neonatology 2011;100:85-92.

69 Meluzin J, Spinarova L, Bakala J, Toman J, Krejci J, Hude P, Kara T, Soucek M: Pulsed doppler tissue imaging of the velocity of tricuspid annular systolic motion; a new, rapid, and non-invasive method of evaluating right ventricular systolic function. Eur Heart J 2001;22:340-348
70 Koestenberger M, Ravekes W, Everett AD, Stueger HP, Heinzl B, Gamillscheg A, Cvirn G, Boysen A, Fandl A, Nagel B: Right ventricular function in infants, children and adolescents: reference values of the tricuspid annular plane systolic excursion (TAPSE) in 640 healthy patients and calculation of $\mathrm{z}$ score values. J Am Soc Echocardiogr 2009;22:715-719.

71 Lang RM, Badano LP, Mor-Avi V, Afilalo J, Armstrong A, Ernande L, Flachskampf FA, Foster E, Goldstein SA, Kuznetsova T, Lancellotti P, Muraru D, Picard MH, Rietzschel ER, Rudski L, Spencer KT, Tsang W, Voigt JU: Recommendations for cardiac chamber quantification by echocardiography in adults: an update from the American Society of Echocardiography and the European Association of Cardiovascular Imaging. Eur Heart J Cardiovasc Imaging 2015;16:233-270.

72 Arce OX, Knudson OA, Ellison MC, Baselga P, Ivy DD, Degroff C, Valdes-Cruz L: Longitudinal motion of the atrioventricular annuli in children: Reference values, growth related changes, and effects of right ventricular volume and pressure overload. J Am Soc Echocardiogr 2002;15:906-916.

73 Levy PT, Dioneda B, Holland MR, Sekarski TJ, Lee CK, Mathur A, Cade WT, Cahill AG, Hamvas A, Singh GK: Right ventricular function in preterm and term neonates: Reference values for right ventricle areas and fractional area of change. J Am Soc Echocardiogr 2015; 28:559-569.

74 Yates AR, Welty SE, Gest AL, Cua CL: Myocardial tissue Doppler changes in patients with bronchopulmonary dysplasia. J Pediatr 2008;152:766-770.e1.

75 Pena JL, da Silva MG, Alves JM Jr, Salemi VM, Mady C, Baltabaeva A, Sutherland GR: Sequential changes of longitudinal and radial myocardial deformation indices in the healthy neonate heart. J Am Soc Echocardiogr 2010; 23:294-300.

76 Al-Naami GH: Torsion of young hearts: a speckle tracking study of normal infants, children, and adolescents. Eur J Echocardiogr 2010;11:853-862. 